\title{
Oral Glucose Tolerance Test with Cooked Rhizomes of Zingiber Officinale (Ginger)
}

\author{
Mohammed Abdul Mannan ${ }^{1}$, Khoshnur Jannat ${ }^{2}$, Mohammed Rahmatullah ${ }^{2 *}$ \\ ${ }^{1}$ Department of Unani Medicine, Faculty of Unani and Ayurvedic Medicine, Hamdard University of Bangladesh, Munshigonj, Dhaka, Bangladesh \\ ${ }^{2}$ Department of Biotechnology \& Genetic Engineering, University of Development Alternative, Lalmatia, Dhaka, Bangladesh
}

*Corresponding author: Prof. Mohammed Rahmatullah, Faculty of Life Sciences, University of Development Alternative, House 4/4, Block-A, Lalmatia, Dhaka-1207, Bangladesh; Tel: +88 0171503262; Email: rahamatm@hotmail.com

Received: December 01; Accepted: December 12, 2018; Published: January 02, 2019;

\begin{abstract}
Rhizomes of Zingiber officinale (ginger) are used as a spice in many culinary dishes of Bangladesh. Since a number of scientific reports are present on the beneficial effects of raw ginger in Type 2 diabetes mellitus, it was of interest to determine the anti-hyperglycemic efficacy of cooked (boiled) ginger through oral glucose tolerance test (OGTT) in mice. The OGTT results showed that when administered at doses of 50, 100, $200 \mathrm{and} 400 \mathrm{mg}$ per kg body weight, methanolic extract of cooked ginger (MEZOC) reduced blood glucose in glucose-loaded mice by 8.0, 20.3, 29.2, and 32.0\%, respectively. By comparison, a standard antihyperglycemic drug, glibenclamide, when administered at a dose of $10 \mathrm{mg}$ per $\mathrm{kg}$, reduced blood glucose levels by $48.8 \%$. The results suggest that cooked ginger retains efficiency in lowering blood glucose. Since cooking causes ginger to be less pungent, partaking of ginger in such a manner may prove to be more acceptable to diabetic patients and help control their blood glucose concentrations.
\end{abstract}

Key words: diabetes, ginger, OGTT, Zingiber officinale, Zingiberaceae

\section{Introduction}

The prevalence of diabetes and particularly Type 2 diabetes is increasing throughout the world. [1] The disease is characterized by high blood glucose levels (hyperglycemia) and cannot be completely cured with allopathic or traditional medicines, although drugs are available to reduce elevated blood glucose levels. Left unchecked, hyperglycemia can lead to both microvascular and macrovascular complications. [2] Since blood glucose and any other associated complications arising from diabetes needs continuous monitoring and may necessitate visits to doctors and taking of costly drugs, treatment is costly and on the most part unaffordable and unavailable to the rural population and particularly the poorer sections of the rural people of Bangladesh. As such, the rural people of Bangladesh and indeed many other countries are dependent on traditional medicinal practitioners, who mostly use plant-based medicines for lowering elevated blood glucose [3].

The rhizomes of Zingiber officinale Roscoe (Zingiberaceae), otherwise known as ginger have found use in ethnomedicine for treatment of diabetes. [4] Different scientific studies have also shown that ginger can reduce hyperglycemia and ameliorate diabetesinduced complications. [4-6] However, in the various scientific studies conducted thus far on humans or animals, either raw ginger or dried ginger powder or various solvent extracts of raw or dried ginger were used. Ginger is a very popular spice in Bangladesh and used in a number of culinary dishes. People also drink hot tea in which raw ginger slices have been steeped to alleviate coughs, cold and sore throat. Raw ginger is pungent in taste and is often disliked. On the other hand cooked or boiled ginger loses the pungency and can be consumed without any possible dislikes. It was therefore of interest to determine whether cooked (boiled) rhizome slices of $Z$. officinale retains its antihyperglycemic property as determined through oral glucose tolerance test (OGTT). The objective of the present study was to evaluate the oral glucose tolerance efficacy of methanol extracts of cooked rhizomes of $Z$. officinale (MEZOC).

\section{Methods and Materials}

\section{Plant material collection}

Rhizomes of $Z$. officinale were collected from a vegetable market in Dhaka city. The rhizomes were identified by a competent botanist at the University of Development Alternative.

\section{Preparation of methanolic extract of cooked Z. Officinale rhizomes (MEZOC)}

For preparation of methanol extract of cooked rhizomes of $Z$. officinale, rhizomes were sliced and cooked (boiled) in water for 30 minutes. $50 \mathrm{~g}$ of the powder was extracted with $250 \mathrm{ml}$ methanol over 48 hours. Methanol was evaporated at $40^{\circ} \mathrm{C}$ and the extract was dissolved in Tween 20 prior to administration to mice by gavaging. The final weight of the extract was $2.17 \mathrm{~g}$.

\section{Chemicals and Drugs}

Glibenclamide and glucose were obtained from Square Pharmaceuticals Ltd., Bangladesh. All other chemicals were of analytical grade. Glucometer and strips were purchased from Lazz Pharma, Bangladesh. 


\section{Animals}

Swiss albino mice were used in the present study. The animals were of both sexes and weighed between 18-20g. Mice were obtained from the International Centre for Diarrhoeal Disease Research, Bangladesh (ICDDR,B). The animals were acclimatized for three days prior to actual experiments. During this time, the animals were fed with mice chow (supplied by ICDDR,B) and water ad libitum. The study was conducted following approval by the Institutional Animal Ethical Committee of University of Development Alternative, Dhaka, Bangladesh. Care was taken that the animals did not suffer from any unnecessary pain during the acclimatization or experimental period.

\section{Oral Glucose Tolerance Tests For Evaluation Of Antihyperglycemic Activity}

Oral glucose tolerance test (OGTT) was carried out as per the procedure previously described by Joy and Kuttan [7] with slight modification. Mice fasted for 12 hours were grouped into six groups of five mice each. The various groups received different treatments like Group 1 received vehicle ( $1 \%$ Tween 20 in water, $10 \mathrm{ml} / \mathrm{kg}$ body weight) and served as control, Group 2 received standard drug (glibenclamide, $10 \mathrm{mg} / \mathrm{kg}$ body weight). Groups 3-6 received, respectively, MEZOC at doses of 50,100, 200 and $400 \mathrm{mg}$ per kg body weight. The amount of Tween 20 administered was same in both control and experimental mice. Following a period of one hour as described earlier, all mice were orally administered $4 \mathrm{~g}$ glucose per $\mathrm{kg}$ of body weight. Blood samples were collected 120 minutes after the glucose administration through puncturing heart following previously published procedures. Blood glucose levels were measured with a glucometer. The percent lowering of blood glucose levels were calculated according to the formula described below.

Percent lowering of blood glucose level $=\left(1-\mathrm{W}_{\mathrm{e}} / \mathrm{W}_{\mathrm{c}}\right) \times 100$,

where $\mathrm{W}_{\mathrm{e}}$ and $\mathrm{W}_{\mathrm{c}}$ represents the blood glucose concentration in glibenclamide or MEZOC administered mice (Groups 2-6), and control mice (Group 1), respectively [8].

\section{Statistical analysis}

Experimental values are expressed as mean \pm SEM. Independent Sample t-test was carried out for statistical comparison. Statistical significance was considered to be indicated by a $\mathrm{p}$ value $<0.05$ in all cases [8].

\section{Results}

When administered at doses of 50, 100, 200 and $400 \mathrm{mg}$ per $\mathrm{kg}$ body weight, methanolic extract of cooked ginger (MEZOC) reduced blood glucose in glucose-loaded mice by $8.0,20.3,29.2$, and $32.0 \%$, respectively. By comparison, a standard antihyperglycemic drug, glibenclamide, when administered at a dose of $10 \mathrm{mg}$ per $\mathrm{kg}$, reduced blood glucose levels by $48.8 \%$. The results suggest that even after boiling, $Z$. officinale rhizomes can be effective in their antihyperglycemic or blood glucose reducing capacities. The results are shown in (Table 1).
Table 1. Lowering action of MEZOC on blood glucose level in hyperglycemic mice following 120 minutes of glucose loading.

\begin{tabular}{|l|c|c|c|}
\hline \multicolumn{1}{|c|}{ Treatment } & $\begin{array}{c}\text { Dose (mg/kg } \\
\text { body weight) }\end{array}$ & $\begin{array}{c}\text { Blood glucose } \\
\text { level (mmol/l) }\end{array}$ & $\begin{array}{c}\text { \% lowering of } \\
\text { blood glucose } \\
\text { level }\end{array}$ \\
\hline Control & $10 \mathrm{ml}$ & $6.70 \pm 0.14$ & - \\
\hline Glibenclamide & $10 \mathrm{mg}$ & $3.42 \pm 0.10$ & $48.8^{*}$ \\
\hline (MEZOC) & $50 \mathrm{mg}$ & $6.16 \pm 0.11$ & $8.0^{*}$ \\
\hline (MEZOC) & $100 \mathrm{mg}$ & $5.34 \pm 0.19$ & $20.3^{*}$ \\
\hline (MEZOC) & $200 \mathrm{mg}$ & $4.74 \pm 0.18$ & $29.2^{*}$ \\
\hline (MEZOC) & $400 \mathrm{mg}$ & $4.22 \pm 0.12$ & $37.0^{*}$ \\
\hline $\begin{array}{l}\text { All administrations were made orally. Values represented as mean } \pm \text { SEM (standard } \\
\text { error of mean), }(\mathrm{n}=5) ; * \mathrm{P}<0.05 ; \text { significant compared to hyperglycemic control } \\
\text { animals. }\end{array}$ &
\end{tabular}

\section{Discussion}

The active component of ginger for its glucose lowering effect has been attributed to 6-gingerol.[9] The compound has not been described to be a volatile compound, but rather produced through thermal degradation of gingerols or shogaols.[10] This can explain the finding that cooked or boiled ginger can retain its blood glucose lowering effect. Overall, the results suggest that boiled ginger can be consumed by diabetic persons to lower their blood glucose, but the amounts to be consumed need to be scientifically studied.

\section{Authorship}

All authors contributed to the design and actual conducting of the experiment. The corresponding author wrote the manuscript, which was read and approved by all authors.

\section{Acknowledgment}

The authors are grateful to Mr. Sohel for assistance during the experiment and to the University of Development Alternative for providing space for maintaining mice and conducting the experiment. The work was funded by the authors.

\section{References}

1. Kalra S, Kumar A, Jarhyan P, Unnikrishnan AG (2015) Endemic or epidemic? Measuring the endemicity index of diabetes. Indian J Endocrinol Metab 19: 5-7. [crossref]

2. Fowler MJ (2016) Microvascular and macrovascular complications in diabetes mellitus: Distinct or continuum. Indian J Endocrinol Metab 29: 116-122.

3. Ocvirk S, Kistler M, Khan S, Talukder SH (2013) Traditional medicinal plants used for the treatment of diabetes in rural and urban areas of Dhaka, Bangladesh-an ethnobotanical survey. J Ethnobiol Ethnomed 9: 43.

4. Wang J, Ke W, Bao R, Hu X (2017) Beneficial effects of ginger Zingiber officinale Roscoe on obesity and metabolic syndrome: a review. Ann N Y Acad Sci 1398: 83-98.

5. Shidfar F, Rajab A, Rahideh T, Khandouzi N, Hosseini S, et al. (2015) The effect of ginger (Zingiber officinale) on glycemic markers in patients with type 2 diabetes. $J$ Complement Integr Med 12: 165-170. [crossref]

6. Akhani SP, Vishwakarma SL, Goyal RK (2004) Anti-diabetic activity of Zingiber officinale in streptozotocin-induced type I diabetic rats. $J$ Pharm Pharmacol 56: 101-105.

7. Joy KL, Kuttan R (1999) Anti-diabetic activity of Picrorrhiza kurroa extract. $J$ Ethnopharmacol 67: 143-148. [crossref] 
8. Hossain AI, Faisal M, Rahman S, Jahan R (2014) A preliminary evaluation of antihyperglycemic and analgesic activity of Alternanthera sessilis aerial parts. $B M C$ Complement Alternat Med 14: 169-173.

9. Chakraborty D, Mukherjee A, Sikdar S, Paul A (2012) [6]-gingerol isolated from ginger attenuates sodium arsenite induced oxidative stress and plays a corrective role in improving insulin signaling in mice. Toxicol Lett 210: 34-43.
10. Zhan K, Wang C, Xu K, Yin H (2008) [Analysis of volatile and non-volatile compositions in ginger oleoresin by gas chromatography-mass spectrometry]. Se Pu 26: 692-696. [crossref]

\section{Citation:}

Mohammed Abdul Mannan, Khoshnur Jannat and Mohammed Rahmatullah (2019) Oral Glucose Tolerance Test with Cooked Rhizomes of Zingiber Officinale (Ginger). Endocrinol Diabetes Metab J Volume 3(1): 1-3. 